Wicaksono, F.Y. · A.M. Nurdin · A.W. Irwan · Y. Maxiselly · T. Nurmala

\title{
Pertumbuhan dan hasil padi hitam yang diberi chlormequat chloride di lahan basah pada musim kemarau
}

\section{Growth and yield of lowland black rice after chlormequat chloride application in dry season}

Diterima : 21 Januari 2019/Disetujui : 12 Desember 2019 / Dipublikasikan : 31 Desember 2019

CDepartment of Crop Science, Padjadjaran University

\begin{abstract}
Black rice is a rice variety that contains the highest anthocyanin pigment. One of the problem of black rice cultivation is the plant height. The plant is too high so it cause plant lodging and decrease yield. This study aims to determine effect of retardant on growth and yield of black rice so the plants are not too high, but still have high productivity. The study used experimental method, that conducted at Ciparanje experimental station, Faculty of Agriculture, University of Padjadjaran, Jatinangor, Sumedang, from March to September 2018. Experimental design used randomized block design. Retardant given was chlormequat chloride (CCC) with a concentration of 1500 ppm. The treatment was application time of CCC in several growth stages, that consisted of: without application (control), application at active vegetative phase, maximum stem length, maximum number of tillers, and flower initiation. All treatments were replicated 4 times. It observed growth and yield component. The results showed that application of CCC gave no significant effect on growth component, but increased some yield component. Chlormequat chloride application at maximum number of tillers or end of vegetative stage gave number of panicle and harvest index that was higher than control.
\end{abstract}

Keywords: Black rice · Retardant · Lowland rice

Sari. Padi hitam merupakan varietas padi yang mengandung pigmen antosianin paling tinggi. Permasalahan budidaya padi hitam yang dikeluhkan oleh petani adalah tanaman terlalu tinggi. Tanaman yang terlalu tinggi dapat

Dikomunikasikan oleh Agus Wahyudin dan Jajang

Sauman Hamdani

Program Studi Agroteknologi Fakultas Pertanian UNPAD

Korespondensi :tati.nurmala@unpad.ac.id menyebabkan tanaman rebah. Penelitian ini bertujuan untuk mengetahui efek retardan terhadap pertumbuhan dan hasil tanaman padi hitam sehingga tidak terlalu tinggi, namun masih memiliki produktivitas yang tinggi. Penelitian menggunakan metode eksperimen yang dilakukan di kebun percobaan Ciparanje, Fakultas Pertanian Universitas Padjadjaran, Jatinangor, Sumedang mulai bulan Maret sampai dengan September 2018. Rancangan percobaan yang digunakan adalah Rancangan Acak Kelompok. Retardan yang diberikan adalah chlormequat chloride (CCC) dengan konsentrasi 1500 ppm. Perlakuan merupakan waktu aplikasi retardan, terdiri dari: tanpa aplikasi (kontrol), aplikasi retardan pada saat vegetatif aktif, pemanjangan batang maksimum, jumlah anakan maksimum, dan inisiasi bunga. Semua perlakuan diulang 4 kali. Pengamatan dilakukan pada komponen pertumbuhan dan hasil. Hasil penelitian menunjukkan bahwa aplikasi CCC tidak memberikan perbedaan nyata terhadap komponen pertumbuhan, namun meningkatkan beberapa komponen hasil. Waktu aplikasi CCC saat jumlah anakan maksimum atau akhir fase vegetatif memberikan jumlah malai dan indeks panen lebih tinggi dibandingkan kontrol.

Kata kunci: Padi hitam $\cdot$ Retardan $\cdot$ Sawah

\section{Pendahuluan}

Padi hitam merupakan varietas padi yang mengandung pigmen antosianin paling tinggi dibandingkan dengan jenis padi yang lain (Suardi dan Ridwan, 2009). Kandungan antosianin dalam produk padi hitam (beras hitam) sekitar $200-400 \mathrm{mg} / 100 \mathrm{~g}$, sementara beras merah hanya $0,33-1,39 \mathrm{mg} / 100 \mathrm{~g}$ dan ketan 
hitam sekitar 109,52 - 256,61 mg/100g. Kandungan antosiasin dalam beras hitam terdapat dalam perikarp, aleuron, dan endosperm yang berwarna merah, biru, dan ungu pekat sehingga terlihat sebagai warna hitam (Purwanto, 2010). Beras hitam juga mempunyai kandungan serat pangan (dietary fiber) dan hemiselulosa yang lebih tinggi dibandingkan beras putih. Kandungan serat pangan dan hemiselulosa beras hitam masingmasing sebesar 7,5\% dan 5,8\%, sementara beras putih mengandung 5,4\% serat pangan dan 2,2\% hemiselulosa (Sa'adah et al., 2013). Selain itu, beras hitam memiliki kandungan zat besi tiga kali lipat lebih banyak, serta asam amino, kalium, kalsium, magnesium, dan flavonoid lima kali lebih banyak dibandingkan dengan beras putih. Kandungan kalori beras hitam lebih rendah dibandingkan dengan beras lain yaitu hanya 362 kkal per 100 gram (Kereh et al., 2016).

Antosianin pada beras hitam berfungsi sebagai antioksidan yang dapat melindungi tubuh dari radikal bebas. Antosianin juga diketahui dapat menurunkan resiko diabetes, mengurangi level kolesterol dalam darah, serta menghambat perkembangan sel kanker dalam tubuh (Guo et al., 2007 dalam Kushwaha, 2016). Kandungan zat besi yang dimiliki beras hitam dapat dijadikan makanan penambah zat besi pada penderita anemia. Kandungan kalori yang rendah pada beras hitam dapat dijadikan beras untuk program diet serta aman dikonsumsi bagi penderita diabetes dan obesitas (Kereh et al., 2016). Beras hitam merupakan pangan dengan banyak fungsi tambahan sehingga dapat dijadikan pangan fungsional.

Permasalahan budidaya padi hitam yang dikeluhkan oleh petani adalah tanaman terlalu tinggi. Tanaman yang terlalu tinggi dapat menyebabkan tanaman rebah (Wahyuni et al., 2002). Padi hitam juga memiliki umur panen yang panjang sehingga petani tidak menyukai dalam membudidayakan padi hitam. Tanaman yang terlalu tinggi dan umur panen yang panjang dapat diatasi dengan pemberian retardan. Retardan merupakan zat pengatur tumbuh yang dapat menghambat pertumbuhan sehingga tanaman tidak terlalu tinggi dan umur tanaman menjadi lebih pendek (Anosheh et al., 2012).

Retardan merupakan zat pengatur tumbuh yang dapat menghambat pertumbuhan terutama menghambat pada pertumbuhan tinggi tanaman. Retardan bekerja menghambat sintesis giberelin pada bagian tubuh tanaman yang dalam prosesnya sel-sel yang terus membelah membentuk sel yang baru tapi sel yang baru tersebut tidak memanjang (Berova et al., 2002). Contoh retardan adalah chlormequat chloride (CCC), ancymidol, paclobutrazol, daminozide, dan hidrazine maleat.

Pertumbuhan tinggi tanaman jagung dapat ditekan oleh pengaruh konsentrasi paklobutrazol dengan konsentrasi 500 ke 1000 ppm mampu menekan pertumbuhan tinggi sebanyak 19,4 cm sedangkan konsentrasi dari 500 ke 1500 ppm menekan pertumbuhan 38,22 cm (Rizky et al., 2014). Pemberian retardan paklobutrazol juga dapat menghambat pertumbuhan tinggi tanaman padi yang ditandai dengan ruas batang dan panjang batang menjadi lebih pendek sehingga meningkatkan hasil sebesar 8\% (Wahyuni, et al., 2002). Retardan daminozid 200 ppm mempengaruhi jumlah rumpun dan pembungaan pada padi Pandanwangi (Irvan dan Adriana, 2017).

Waktu pemberian retardan juga berpengaruh terhadap pertumbuhan dan hasil tanaman karena berhubungan dengan produksi hormon asam absisat (ABA) secara endogenous (Taiz and Zeiger, 2002). Beberapa penelitian telah menyebutkan waktu pemberian retardan berpengaruh terhadap pertumbuhan dan hasil tanaman, namun belum jelas bagaimana korelasinya (Sambeka et al., 2012; Lienargo et. al., 2014).

Aplikasi retardan pada tanaman tahunan dapat mempercepat pembungaan (Upreti et. al., 2013). Hal yang kontras terjadi pada peningkatan ABA di tanaman sereal. Pengaruh peningkatan konsentrasi ABA memasuki inisiasi pembungaan dapat bervariasi, bisa berlangsung lebih cepat atau lebih lambat (Barnabas et al., 2007). Hal ini dapat menyebabkan umur tanaman berubah lebih pendek atau lebih panjang. Bila terjadi pengurangan umur vegetatif diharapkan hasil tanaman menjadi tinggi karena persentase pembentukan malai meningkat.

Pemberian CCC sebagai retardan pada tanaman padi hitam diharapkan dapat menghambat pertumbuhan tanaman padi hitam dan umur yang lebih pendek. Dengan demikian, hasil padi hitam juga diharapkan dapat meningkat setelah diberi perlakuan CCC. 


\section{Bahan dan Metode}

Bahan yang digunakan untuk percobaan ini benih padi hitam yaitu benih varietas lokal Tasikmalaya, zat pengatur tumbuh retardan chlormequat chloride (CCC), pupuk urea, $\mathrm{KCl}$, SP-36, kompos sekam padi, pupuk kandang ayam, insektisida berbahan aktif pymetrozin dan buprofezin serta fungisida mankozeb. Alat yang digunakan untuk percobaan ini adalah peralatan budidaya, meteran, seed moisture tester, neraca digital, alat tulis, serta alat dokumentasi.

Penelitian ini dilakukan di Kebun Percobaan Ciparanje, Fakultas Pertanian, Universitas Padjadjaran, Jatinangor, Sumedang. Ketinggian tempat lokasi penelitian sekitar $750 \mathrm{~m}$ di atas permukaan laut (dpl), dengan tipe iklim C3 menurut klasifikasi Oldeman. Suhu rata-rata adalah $23,8^{\circ} \mathrm{C}$. Jenis tanah di areal penelitian adalah Inseptisol dengan $\mathrm{pH}$ tanah 5,83. Penelitian dilaksanakan mulai bulan Maret sampai dengan November 2018.

Penelitian aplikasi retardan menggunakan metode eksperimen. Rancangan percobaan adalah Rancangan Acak Kelompok (RAK). Perlakuan terdiri dari berbagai waktu aplikasi CCC berdasarkan umur/fase pertumbuhan tanaman, yaitu:

A : tanpa aplikasi CCC (kontrol)

B : aplikasi CCC pada saat vegetatif aktif (6 Minggu Setelah Tanam (MST))

$\mathrm{C}$ : aplikasi CCC pada saat pemanjangan batang maksimum (8 MST)

D : aplikasi CCC pada saat anakan maksimum (10 MST)

E : aplikasi CCC pada saat inisiasi bunga (bunting) (12 MST)
Semua perlakuan diulang 3 kali. Plot percobaan berukuran $2 \times 3$ meter persegi. Konsentrasi CCC yang digunakan adalah 1500 ppm. Chlormequat chloride diaplikasikan dengan cara disemprotkan pada permukaan daun.

Pengamatan dilakukan pada komponen pertumbuhan dan komponen hasil tanaman padi hitam. Komponen pertumbuhan yang diamati adalah tinggi tanaman, jumlah anakan, indeks luas daun (ILD), bobot kering biomassa total, umur berbunga. Komponen hasil yang diamati adalah jumlah malai, bobot 1000 butir, jumlah biji per malai, persentase gabah isi, dan indeks panen.

\section{Hasil dan Pembahasan}

Perlakuan CCC tidak memberikan perbedaan nyata dibandingkan perlakuan tanpa aplikasi retardan pada komponen pertumbuhan padi hitam. Tinggi tanaman, jumlah anakan, ILD, bobot kering tanaman, serta umur berbunga tidak dipengaruhi oleh perlakuan CCC (Tabel 1).

Pemberian CCC tidak menunjukkan pengaruh yang berbeda nyata terhadap tinggi tanaman. Beberapa percobaan juga pernah melaporkan bahwa pemberian retardan CCC tidak memberikan pengaruh terhadap tinggi tanaman padi, seperti yang dilakukan Gurmani et al. (2006). Tidak adanya pengaruh pemberian CCC pada tinggi tanaman padi diduga akibat dari pengaruh suhu selama fase pertumbuhan tanaman. Suhu selama percobaan memiliki ratarata $24^{\circ} \mathrm{C}$ dan tergolong pada suhu optimum yang dibutuhkan tanaman padi (Badan Ketahanan Pangan dan Penyuluh Pertanian Aceh, 2009).

Tabel 1. Komponen pertumbuhan padi hitam setelah aplikasi CCC.

\begin{tabular}{|c|c|c|c|c|c|}
\hline Perlakuan & $\begin{array}{c}\text { Tinggi } \\
\text { tanaman } 14 \\
\text { MST }(\mathrm{cm})\end{array}$ & $\begin{array}{c}\text { Jumlah } \\
\text { Anakan } 14 \\
\text { MST }\end{array}$ & $\begin{array}{c}\text { Indeks } \\
\text { Luas Daun } \\
14 \mathrm{MST}\end{array}$ & $\begin{array}{c}\text { Bobot } \\
\text { kering } \\
\text { tanaman } 14 \\
\text { MST }(\mathrm{g})\end{array}$ & $\begin{array}{c}\text { Umur } \\
\text { berbunga } \\
\text { (hari } \\
\text { setelah } \\
\text { tanam) }\end{array}$ \\
\hline tanpa aplikasi CCC (kontrol) & $115.06 \mathrm{a}$ & $29.68 \mathrm{a}$ & $6.57 \mathrm{a}$ & $126.90 \mathrm{a}$ & $101.75 \mathrm{a}$ \\
\hline aplikasi saat vegetatif aktif & $116.00 \mathrm{a}$ & $28.58 \mathrm{a}$ & $6.57 \mathrm{a}$ & $122.92 \mathrm{a}$ & $101.25 \mathrm{a}$ \\
\hline $\begin{array}{l}\text { aplikasi saat pemanjangan } \\
\text { batang maksimum }\end{array}$ & $110.89 \mathrm{a}$ & $28.68 \mathrm{a}$ & $6.17 \mathrm{a}$ & $116.39 \mathrm{a}$ & $101.5 \mathrm{a}$ \\
\hline $\begin{array}{l}\text { aplikasi saat jumlah anakan } \\
\text { maksimum }\end{array}$ & $114.03 \mathrm{a}$ & $29.50 \mathrm{a}$ & $6.59 \mathrm{a}$ & $115.85 \mathrm{a}$ & $101 \mathrm{a}$ \\
\hline aplikasi saat fase inisiasi bunga & $114.13 \mathrm{a}$ & $28.55 \mathrm{a}$ & $6.62 \mathrm{a}$ & $117.02 \mathrm{a}$ & $102 \mathrm{a}$ \\
\hline
\end{tabular}

Keterangan: Angka yang diikuti dengan huruf yang sama tidak berbeda nyata berdasarkan uji jarak berganda Duncan pada taraf nyata $5 \%$. 
Tabel 2. Komponen hasil padi hitam setelah aplikasi CCC.

\begin{tabular}{lccccc}
\hline \multicolumn{1}{c}{ Perlakuan } & $\begin{array}{c}\text { Bobot } 1000 \\
\text { butir }\end{array}$ & $\begin{array}{c}\text { Jumlah biji } \\
\text { per malai }\end{array}$ & $\begin{array}{c}\text { Persentase } \\
\text { gabah isi } \\
(\%)\end{array}$ & $\begin{array}{c}\text { Jumlah } \\
\text { malai per } \\
\text { rumpun }\end{array}$ & $\begin{array}{c}\text { Indeks } \\
\text { panen }\end{array}$ \\
\hline $\begin{array}{l}\text { tanpa aplikasi retardant (kontrol) } \\
\text { aplikasi saat vegetatif aktif }\end{array}$ & $25.50 \mathrm{a}$ & $142.85 \mathrm{a}$ & $55.69 \mathrm{a}$ & $21.60 \mathrm{ab}$ & $0.27 \mathrm{a}$ \\
$\begin{array}{l}\text { aplikasi saat pemanjangan } \\
\text { batang maksimum }\end{array}$ & $25.66 \mathrm{a}$ & $142.10 \mathrm{a}$ & $63.31 \mathrm{a}$ & $21.75 \mathrm{ab}$ & $0.29 \mathrm{ab}$ \\
$\begin{array}{l}\text { aplikasi saat jumlah anakan } \\
\text { maksimum }\end{array}$ & $25.67 \mathrm{a}$ & $149.75 \mathrm{a}$ & $68.75 \mathrm{a}$ & $19.55 \mathrm{a}$ & $0.31 \mathrm{bc}$ \\
aplikasi saat fase inisiasi bunga & $140.25 \mathrm{a}$ & $59.44 \mathrm{a}$ & $24.80 \mathrm{c}$ & $0.33 \mathrm{c}$ \\
\hline
\end{tabular}

Keterangan: Angka yang diikuti dengan huruf yang sama tidak berbeda nyata berdasarkan uji jarak berganda Duncan pada taraf nyata $5 \%$.

Retardan CCC bekerja efektif pada suhu yang relatif rendah (Rademacher, 2016) sehingga tidak berpengaruh pada tinggi tanaman.

Pertumbuhan tanaman meningkat secara linear dengan peningkatan suhu (Yoshida, 1981). Peningkatan tinggi tanaman dapat diakibatkan oleh tingginya kandungan giberelin dalam tanaman yang disebabkan suhu tinggi sehingga tanaman mengalami peningkatan pembelahan dan perpanjangan sel (Hamdani, 2009). Dengan demikian, konsentrasi CCC yang diberikan mungkin tidak cukup untuk menghambat sintesis giberelin.

Teknik aplikasi CCC juga memiliki pengaruh terhadap keefektifan dalam menghambat sintesis giberelin pada tanaman. Retardan CCC pada percobaan ini disemprotkan ke permukaan daun, hal ini membuatnya kurang efektif untuk memperpendek tinggi tanaman. Wiraatmaja (2017) menyatakan bahwa pemberian retardan CCC dan ancymidol lebih efektif diaplikasikan melalui akar dibanding melalui permukaan daun untuk menghasilkan tanaman yang pendek.

Berdasarkan analogi pada tinggi tanaman, maka jumlah anakan, ILD, dan bobot kering tanaman tidak dipengaruhi oleh CCC yang kemungkinan disebabkan oleh konsentrasi CCC tidak cukup untuk menghambat sintesis giberelin. Pertumbuhan tanaman yang pesat diakibatkan oleh kandungan giberelin yang tinggi dalam metabolisme tanaman (Hamdani, 2009).

Umur berbunga juga tidak dipengaruhi oleh aplikasi CCC. Hal ini dapat diakibatkan oleh beberapa kemungkinan. Pertama, konsentrasi CCC masih rendah sehingga tidak memicu peningkatan hormon ABA untuk memicu pembungaan. Peningkatan ABA di beberapa tanaman sereal dapat mempengaruhi inisiasi pembungaan kemudian mempengaruhi umur berbunga (Barnabas, 2007). Kedua, konsentrasi retardan dilaporkan banyak berpengaruh pada tanaman tahunan (Upreti et al., 2013), jarang dilaporkan pada tanaman semusim.

Pemberian CCC tidak berpengaruh pada beberapa komponen hasil, seperti bobot 1000 butir, jumlah biji per malai, dan persentase gabah isi. Beberapa waktu pemberian CCC memberikan perbedaan pada komponen hasil lainnya dibandingkan kontrol, yaitu jumlah malai per rumpun dan indeks panen (Tabel 2).

Pemberian CCC tidak berpengaruh terhadap bobot 1000 butir padi hitam. Selaras dengan penelitian Tabatabaei dan Akhgari (2014) bahwa pemberian CCC tidak menunjukkan perbedaan nyata pada bobot 1000 butir tanaman padi. Retardan jenis paclobutrazol tidak menunjukan perbedaan yang signifikan terhadap bobot 100 butir hanjeli batu (Nurmala et al., 2017). Tidak terdapatnya perbedaan yang signifikan pada bobot 1000 butir diduga akibat dari genetik kultivar tersebut dan kondisi kesuburan tanah yang optimal bagi tanaman sehingga tidak mempengaruhi tingkat kenaikan maupun penurunan bobot butir padi (Nurmala et al., 2017).

Pada penelitian ini tidak terdapat perbedaan nyata terhadap jumlah biji per malai dan persentase bulir isi setelah diaplikasikan CCC. Analogi yang sama dengan bobot 1000 butir, pemberian CCC tidak berpengaruh terhadap jumlah malai dan persentase bulir isi. Hal ini selaras dengan percobaan Akinrinde (2006) yang melaporkan bahwa pemberian retardan CCC tidak menunjukkan perbedaan yang signifikan terhadap pengisian biji dan jumlah bulir yang terbentuk pada tanaman padi kultivar OS-6 dan IR-5. 
Pengaruh dari pemberian CCC yang diaplikasikan pada saat jumlah anakan maksimum dan saat fase inisiasi bunga memberikan jumlah malai yang lebih tinggi dibandingkan kontrol. Hal ini sesuai dengan percobaan yang dilakukan oleh Wahyuni (2002) melaporkan bahwa pemberian zat penghambat pertumbuhan mampu meningkatkan jumlah malai yang terbentuk. Waktu pemberian retardan berpengaruh terhadap pertumbuhan dan hasil tanaman karena berhubungan dengan produksi hormon ABA secara endogenous (Taiz and Zeiger, 2002).

Pemberian CCC berpengaruh terhadap indeks panen tanaman padi. Aplikasi saat pemanjangan batang maksimum, saat jumlah anakan maksimum, atau saat fase inisiasi bunga berbeda nyata dengan kontrol. Keadaan berbeda dihasilkan oleh perlakuan aplikasi retardan saat fase vegetatif aktif yang memberikan indeks panen yang sama dengan tanpa aplikasi retardan. Terjadinya perbedaan indeks panen yang signifikan setelah pemberian CCC terjadi karena hasil fotosintat yang disimpan dalam bentuk bulir menjadi berbeda. Pemberian CCC menghambat proses pembentukan giberelin sehingga laju pertumbuhan menjadi terhambat. Kandungan klorofil dalam daun mengalami peningkatan konsentrasi meski terjadi penghambatan laju pertumbuhan (Wahyuni et al., 2002) sehingga diduga proses fotosintesis terjadi peningkatan dan fotosintat yang dihasilkan didistribusikan untuk pengisian bulir padi. Pemberian retardan paclobutrazol mampu meningkatkan indeks panen pada tanaman Tef (Eragrotis tef (Zucc.)) pada stadia anakan dan pemanjangan batang (Tesfahun, 2017).

\section{Simpulan dan Saran}

Hasil penelitian menunjukkan bahwa aplikasi CCC pada tanaman padi hitam di lahan kering belum dapat menghambat komponen pertumbuhan, namun meningkatkan beberapa komponen hasil, yaitu jumlah malai dan indeks panen. Waktu aplikasi saat jumlah anakan maksimum atau akhir vegetatif merupakan waktu aplikasi CCC terbaik dibandingkan tanpa aplikasi retardan.

Saran dari penelitian ini adalah mencoba beberapa dosis CCC atau retardan yang lain pada beberapa fase tumbuh tanaman untuk menghambat pertumbuhan tanaman padi hitam terutama pada musim hujan. Hujan dengan intensitas tinggi sering menyebabkan rebah pada tanaman padi hitam.

\section{Daftar Pustaka}

Akinrinde, E. A. 2006. Growth regulator and nitrogen fertilization effects on performance and nitrogen-use efficiency of tall and dwarf varieties of rice (Oryz sativa L.). Biotechnology, 5(3), 268-276.

Anosheh, H. P., Y. Emam, M. Ashraf, and M. R. Foolad. 2012. Exogenous application of salicylic acid and chlormequat chloride alleviates negative effects of drought stress in wheat. Advanced Studies in Biology, 4(11): 501 - 520.

Badan Ketahanan Pangan dan Penyuluh Pertanian Aceh. 2009. Budidaya Tanaman Padi. Balai Pengkajian Teknologi Pertanian Provinsi NAD, 1-20.

Barnabas, B., K. Jager, and A. Feher. 2007. The effect of drought and heat stress on reproductive processes in cereals. Plant, Cell, and Environ. Vol. 31 (1): 11 - 38.

Berova, M., Z. Zlatev, and N. Stoeva. 2002. Effect of paclobutrazol on wheat seedlings under low temperature stress. Bulg. J. Plant Physiol. Vol. 28 (1-2): 75-84.

Gurmani, A. R., Bano, A., \& Salim, M. 2006. Effect of growth regulators on growth, yield and ions accumulation of Rice (Oryza sativa L .) under salt stress. Pakistan Journal of Botany, 38(5), 1415-1424.

Hamdani, J. S. 2009. Pengaruh jenis mulsa terhadap pertumbuhan dan hasil tiga kultivar kentang (Solanum tuberosum L.) yang ditanam di dataran medium. J. Agron. Indonesia, 37(1), 14-20.

Irvan, A. dan A. Adriana. 2017. Pengaruh zat pengatur tumbuh (zpt) daminozid dan giberelin terhadap pertumbuhan dan pembungaan padi pandanwangi. Agroscience. Vol. 7 (2): 281 - 288.

Kereh, B. C., Mayulu, N., dan Kawengian, S. E. 2016. Gambaran kandungan zat- Zat gizi pada beras hitam ( Oryza sativa L .) Varietas Enrekang. Diambil dari https:// ejournal.unsrat.ac.id/index.php/e biomedik/article/viewFile/11053/10642 pada tanggal 20 Mei 2017 
Kushwaha, U. K. 2016. Black Rice. Springer International Publishing, 21-48. https://doi.org/10.1007/978-3-319-30153-2

Lienargo, B. R., S. R. Runtunuwu, J. E. X. Rogi, dan P. Tumewu. 2014. pengaruh waktu penyemprotan dan konsentrasi paclobutrazol (pbz) terhadap pertumbuhan dan produksi tanaman jagung (Zea mays L.) varietas Manado Kuning. Cocos. Vol. 4 (1): 1 - 9 .

Nurmala, T., Ruminta, \& Wahyudin, A. 2017. Respons pertumbuhan dan hasil tanaman hanjeli batu (Coix lacryma- jobi L.) akibat pupuk silika cair dan paclobutrazol. Jurnal Kultivasi, 16(3), 474-481.

Purwanto, E. 2010. Manfaat Beras Hitam. Diambil dari https://uns.ac.id/id/unsupdate/ini-dia-berbagai-manfaat-berashitam.html pada tanggal 20 Mei 2017

Rademacher, W. 2016. Chemical Regulators of Gibberellin Status and Their Application in Plant Production. (Vol. 49). Annual Plant Reviews.

Rizky Bonaventura Lienargo, Semuel D. Runtunuwu, Johannes E.X. Rogi, dan Pemmy Tumewu. 2014. Pengaruh waktu penyemprotan dan konsentrasi Paclobutrazol (pbz) terhadap pertumbuhan dan produksi tanaman jagung (zea mays 1.) Varietas manado kuning. Fakultas Pertanian UNSRAT.

Sa'adah, I. R., Supriyanta, dan Subejo. 2013. Keragaman Warna Gabah Dan Warna Beras Varietas Lokal Padi Hitam (Oryza sativa L.) yang Dibudidayakan oleh Petani Kabupaten Sleman, Bantul dan Magelang. Jurnal Vegetalika, 2(3), 13-20. Faperta Universitas Gadjah Mada, Yogyakarta

Sambeka, F., S. D. Runtunuwu, and J. E. X. Rogi. 2012. Efektifitas waktu pemberian dan konsentrasi paclobutrazol terhadap pertumbuhan dan hasil kentang (Solanum tuberosum L.) varietas Supejohn. Eugenia. Vol. 18 (2): 126 - 133.

Suardi, D., dan Ridwan, I. 2009. Beras Hitam, Pangan Berkhasiat yang Belum Populer. Warta Penelitian dan Pengembangan Pertanian, 31(2), 9-10.

Tabatabaei, S. S. M., \& Akhgari, H. 2014. The investigation of growth reducer Cycocel effect on yield and some quantitative characteristics of rice (Oryza sativa) at different nitrogen levels. International J. of Farming and Allied Sciences, 3(2), 197-202.

Taiz, L. and Zeiger, E. 2002. Plant Physiology. Sinnauer Associates. Sunderland.

Tesfahun, W. 2017. Effect of Rates and Time of Paclobutrazol Application on Growth , Lodging, and Yield and Yield Components of Tef [ Eragrostis Tef ( Zucc .) Trotter ] in Adadistrict, East Shewa, Ethiopia. Journal of Biology, Agriculture and Healthcare, 7(13), 23-41.

Upreti, K. K., Y. T. N. Reddy, S. R. Prasad, G. V. Bindu, H. L. Jayaram, and S. Rajan. 2013. Hormonal changes in response to paclobutrazol induced early flowering in mango cv. Totapuri. Scientia Horticulturae. Vol. 150: 414 - 418.

Wahyuni, S., U. R. Sinniah, M. K. Yusop, and R. Amarthalingam. 2002. Effect of paclobutrazol and prohexadione-calcium on growth, lodging resistance and yield of wet seeded rice. Jurnal Penelitian Pertanian Tanaman Pangan. Vol. 21 (3): 24 - 30.

Wiraatmaja, I. W. 2017. Giberelin, Etilen, dan Pemakaiannya dalam Bidang Pertanian. Faperta Universitas Udayana.

Yoshida, S. 1981. Fundamentals of Rice Crop Science. IRRI, 65-109. 